\title{
The Effect of Biogas Waste Doses (Sludge) of Cow Manure on the Growth and the Yield of Eggplant (Solanum Melongena L.)
}

\author{
Ach Fauzan Mas' udi ${ }^{1 *}$, Hidayat Bambang Setyawan², \\ ${ }^{1}$ Study Program of Agrotechnology, Faculty of Agriculture, University of Jember, Jember, Indonesia \\ ${ }^{2}$ Lecturer at the Faculty of Agriculture, University of Jember, Jember, Indonesia
}

\begin{abstract}
The growth and the yield of eggplant plants are strongly influenced by the condition of the soil, and any damage to soil quality can cause unproductive plants according to its potential results. The addition of organic material in the form of biogas waste into the soil is expected to increase the yield of eggplant. This experiment aims at determining the best dose of biogas waste (sludge) to increase eggplant production. The experiment was carried out in Jember Lor village, Patrang, Jember, East Java with an altitude of \pm 89 meters above sea level ( $\mathrm{m}$ asl). The experiment used a completely randomized design method (CRD) with 4 treatments, treatment LO: Okg waste plant ${ }^{-1}$; L1: $0.6 \mathrm{~kg}_{\text {of waste plant }}{ }^{-1}$; L2: $1.2 \mathrm{~kg}$ of waste plants ${ }^{-1}$ and L3: $2.2 \mathrm{~kg}$ of waste plants ${ }^{-1}$. Each treatment was repeated 6 times with a total of 24 plants. Based on the results of the study, there was a very significant effect of sludge on variables of plant height, flowering age, harvesting age, fruit diameter, fruit length, and fruit weight. Sludge does not show a significant difference in plant diameter variables. The best treatment to have reached the plant height, fruiting age, harvesting age, fruit diameter, fruit length and fruit weight was the treatment of using a sludge with the dose of $1.2 \mathrm{~kg}$ polybag ${ }^{-1}(\mathrm{~L} 2)$ with a height of $102.8 \mathrm{~cm}$, different ages of $30.83 \mathrm{HST}$, harvest age of $56.73 \mathrm{HST}$, fruit diameter of $35.93 \mathrm{~mm}$, fruit length of $17.95 \mathrm{~cm}$ and fruit weight of crop reached $1.36 \mathrm{~kg}$ (37.61 tons ha-1).
\end{abstract}

Keywords: biogas waste, cow dung, eggplant, sludge.

\section{INTRODUCTION}

Eggplant (Solanum melongena L.) is a tropic native plan originating from the Asian continent, especially India and Burma. Eggplant is a vegetable plant that includes in the eggplantfamily (Solanaceae). Eggplants become everyone's favorite vegetable, both as fresh vegetables and processed into various types of cuisine [1]. Eggplant contains various kinds of nutrition. Every 100 grams of fresh eggplant contains $24 \mathrm{~g}$ of calories, $1.1 \mathrm{~g}$ of protein, $0.2 \mathrm{~g}$ of fat, $5.5 \mathrm{~g}$ of carbohydrates, $15 \mathrm{mg}$ of calcium, $37.0 \mathrm{mg}$ of phosphorus, $0.4 \mathrm{mg}$ of iron, $4.0 \mathrm{mg}$ of Vitamin A, $5 \mathrm{mg}$ of Vitamin C, $0.04 \mathrm{mg}$ vitamin $\mathrm{B} 1$, and $92.7 \mathrm{~g}$ of water [2].

The demand for eggplants continues to increase, but the demand escalation is not accompanied by an increase in the amount of production. One of them is caused by the low productivity of eggplant. Indonesia has an average production of eggplant ranging from $9.38-10.95$ tons hectare ${ }^{-1}$. Whereas, the onehectare area actually can produce 30 tons of eggplant [3]. Some damages to soil quality cause more unproductive plants according to the

${ }^{*}$ Correspondence Address:

Ach Fauzan Mas'udi

E-mail : Kubortters@gmail.com

Address : University of Jember, St. Kalimantan 37 Jember, 68121. potential results.

The use of excessive inorganic fertilizers without being followed by organic fertilizers causes damage to the soil. Damage to the soil resulted in the inefficiency fertilizer due to the loss of fertilizer from the soil through erosion, leaching and binding by other compounds. Adding green manure and organic fertilizer can be made as an effort to reduce the loss of fertilizer [4].

Biogas waste is an appropriate organic material from daily livestock waste for sustainable, environmentally friendly and pollution-free agricultural production. Biogas waste can increase the agricultural production due to nutrient content, enzymes and growth hormones contained in it. Biogas waste fertilizer has the same benefits as manure to improve soil structure and provide nutrients needed by plants [5]. Organic manures play a direct role in soil fertility, microbial population, improves plant growth by providing micro and macronutrients in available form, which eventually increased productivity [6].

Provision of biogas organic fertilizer from cow manure with a concentration of $20 \mathrm{~mL}^{-\mathrm{L}^{-1}}$ of water plot $^{-1}$ can increase the yield of sweet corn 0.8 ton ha ${ }^{-1}$ [7]. Addition of $300 \mathrm{~mL}$ biogas wastes plants $^{-1}$ can increase plant height, a number of leaves and diameter of oil palm plant seedlings. 
Utilization of cow biogas waste to increase crop productivity has not been done. The purpose of this study was to determine the effect of biogas waste dose (sludge) on the growth and production of eggplant plants.

\section{MATERIAL AND METHOD}

The trial was conducted at the Green House in Jember Lor, Partang, Jember with an altitude of \pm 89 masl and starting from April-November 2018. This experiment used a completely randomized design (CRD) method with 4 treatments. Treatment of LO: $0 \mathrm{~kg}$ of waste polybag $^{-1}$; L1: $0.6 \mathrm{~kg}$ of waste polybag ${ }^{-1}$; L2: $1.2 \mathrm{~kg}$ of waste polybag-1 and L3: $2.2 \mathrm{~kg}$ of waste polybag $^{-1}$. Each treatment was repeated as many as 6 replications with a total of 24 plants.

\section{Extraction and Drying of Biogas Waste}

The used biogas waste came from biogas reactors in Kemungsari Lor village, Panti, Jember. The taken waste was then dried until the water content ranges from $10-40 \%$ to avoid ignoring the elements $\mathrm{N}$ and $\mathrm{P}$.

\section{Media Preparation}

The planting media used were the land originating from Bintoro village, Patrang, Jember. The planting media was in the form of land that had dried up the wind, weighing in as much as $10 \mathrm{~kg}$ and put into polybags size $50 \times 50$. The distance between polybags used was $60 \mathrm{~cm} \mathrm{x}$ $60 \mathrm{~cm}$. After the polybag was prepared, then fertilization was carried out using biogas waste on seven days before planting in accordance with the treatments.

\section{Preliminary Analysis of Soil and Biogas Waste}

The analysis was carried out by taking soil samples and biogas waste which would be used in the study, then, drying the air and sieving using a $2 \mathrm{~mm}$ diameter sieve. While the biogas waste samples were dried until the water content was below $40 \%$. Examples of soil and waste that have been dried were then determined for total $\mathrm{N}$ nutrient levels, total $\mathrm{P}$, total $\mathrm{K}$, organ- $\mathrm{C}$, and $\mathrm{pH}$. $\mathrm{N}$-total was determined by Kjeldahl distillation, $\mathrm{P}$ total was determined using the P-Olsen method, K-total was determined using the $25 \% \mathrm{HCl}$ Extract method while organic $\mathrm{C}$ was carried out by Walkley and Black method and $\mathrm{pH}$ using $\mathrm{H}_{2} \mathrm{O}$ method (1: 2.5).

\section{Seedling}

Seedlings nurseries were planted in $5 \times 10 \mathrm{~cm}$ polybags. The planting media used for the nursery process was compost. Each polybag was filled with one seed. The nursery was carried out for \pm 28 days until it was ready to move with the characteristics of leaves formed as many as 4-6 leaflets.

\section{Planting and Maintaining}

The Eggplant seeds that were 28 days old done trough transferring those into a $50 \times 50 \mathrm{~cm}$ polybag. Each polybag was filled with one seed with a distance of $60 \times 60 \mathrm{~cm}$ polybag. Eggplant plants were planted for 75 days and were observed every 10 days for growth variables. Maintenance includes watering, weeding, and prevention as well as handling physical pest and plant organisms (OPT).

\section{Analysis of Soil Samples After}

The samples of soil were analyzed for organic carbon (C-Organic) and cation exchange capacity (CEC) at 21 days after planting. The analysis was carried out by taking soil samples at each polybag then compositing. Then dry the air and sift using a $2 \mathrm{~mm}$ diameter sieve. The example then set the $\mathrm{CEC}$ and $\mathrm{C}$-organic values.

\section{Data processing}

The data obtained was carried out by the analysis of variance (ANOVA) and then followed by a Duncan multiple range test (DMRT) with a confidence level of $5 \%$ to determine the effect of each treatment on various observed variables.

\section{RESULT AND DISCUSSION}

Characteristics of Land and the Biogas Waste

The preliminary analysis is carried out on the land and biogas waste that will be used. Soil and waste were analyzed at the Laboratory of Soil Fertility, Faculty of Agriculture, University of Jember and also at the Jember Coffee and Cocoa Research Center. Analysis of organic C, ph, N, and $P$ is available at the Laboratory of soil fertility while $\mathrm{K}$ determination is available at the coffee and cocoa research center of Jember district. Analysis of soil and biogas waste aims to determine the characteristics of soil and biogas waste that will be used for research experiments. The following are the results of the preliminary analysis of land and waste used can be seen in Table 1 and Table 2 .

Based on the results of the analysis, nitrogen, phosphorus, and potassium are available in soil and waste. The results of the analysis are used to determine the treatment to be applied. Nutrient requirements for eggplant were $7.22 \mathrm{~g} \mathrm{~N}, 3.36 \mathrm{~g}$ $\mathrm{P}_{2} \mathrm{O}_{5}$ and $2.71 \mathrm{~g} \mathrm{~K}_{2} \mathrm{O}$. Nutrients requitments for eggplant after be demished by nutrients on the $10 \mathrm{~kg}$ soil were $6.22 \mathrm{~g} \mathrm{~N}, 3.60 \mathrm{~g} \mathrm{P}_{2} \mathrm{O}_{5}$ and 2.51 
$\mathrm{K}_{2} \mathrm{O}$. The following is a summary of the calculation of waste requirements as a substitute for nutrient requirements for eggplant.

Table 1. Characteristics of Early Soils before Research

\begin{tabular}{lcccl}
\hline $\begin{array}{l}\text { Items of } \\
\text { Analysis }\end{array}$ & Value & Unit & Standard & Method \\
\hline $\mathrm{C}-O r g a n i c$ & $\%$ & 1.49 & Low & $\mathrm{W} \mathrm{\&} \mathrm{B}$ \\
$\mathrm{pH} \mathrm{H} \mathrm{H}_{2} \mathrm{O}$ & - & 6.76 & Neutral & $\mathrm{pH} \mathrm{Meter}$ \\
$\mathrm{N}$ & $\%$ & 0.1 & Very Low & Kjeldahl \\
$\mathrm{P}_{2} \mathrm{O}_{5}$ & $\mathrm{Ppm}$ & 14.12 & Moderate & Olsen \\
$\mathrm{K}_{2} \mathrm{O}$ & $\%$ & 0.10202 & Very Low & $\mathrm{HCl} 25 \%$ \\
$\mathrm{C} / \mathrm{N}$ Ratio & & 14.9 & Moderate & \\
\hline
\end{tabular}

* Criteria for Assessing the Results of Soil Analysis of the 2009 Soil Research Center

Source: Research Center of Kopi and Kakao Jember and Laboratory of Soil Fertility, University of Jember (2018)

The dose of waste used is based on nutrient requirements needed by eggplant, the number of nutrients in the soil and in the waste of biogas. Calculation of biogas waste requirements can be seen in Table 4. Adding different organic materials to the soil will affect the nature of the soil. Based on the results of the analysis after treatment, the following data are obtained.

Table 2. Results of Biogas Waste Analysis

\begin{tabular}{lcccl}
\hline $\begin{array}{c}\text { Items of } \\
\text { Analysis }\end{array}$ & Unit & Value & $\begin{array}{c}\text { Quality } \\
\text { Standart }\end{array}$ & Description \\
\hline $\mathrm{C}-$ Organic & $\%$ & 14.47 & $>12 \%$ & $\mathrm{M}$ \\
$\mathrm{pH} \mathrm{H} \mathrm{H}_{2} \mathrm{O}$ & - & 7.15 & $4-8$ & $\mathrm{M}$ \\
$\mathrm{N}$ & $\%$ & 0.77 & $2 \%$ & $\mathrm{NF}$ \\
$\mathrm{P}_{2} \mathrm{O}_{5}$ & $\%$ & 0.54 & $2 \%$ & $\mathrm{NF}$ \\
$\mathrm{K}_{2} \mathrm{O}$ & $\%$ & 0.25 & $2 \%$ & $\mathrm{NF}$ \\
$\mathrm{C} / \mathrm{N}$ Ratio & & 18.79 & $10-25$ & $\mathrm{M}$ \\
\hline
\end{tabular}

* Regulation of Indonesia Agriculture Departement No. 28/Permentan/SR.130/B/ 2009.

Description: $M=$ Meets, NF = Not Fulfilling

Source: Research Center of Kopi and Kakao Jember and Laboratory of Soil Fertility, University of Jember (2018)

Table 3. Nutrient Requirements for Eggplant

\begin{tabular}{ccccc}
\hline $\begin{array}{c}\text { Required } \\
\text { Nutrient }\end{array}$ & $\begin{array}{c}\mathrm{Kg} \\
\mathbf{H a}^{-1}\end{array}$ & $\begin{array}{c}\text { Gram } \\
\text { plant }^{-1}\end{array}$ & $\begin{array}{c}\text { Total } \\
\text { plants } \\
\text { Ha }^{-1}\end{array}$ & $\begin{array}{c}\text { Required- } \\
\text { soil }\end{array}$ \\
\hline $\mathrm{N}($ Urea) & 200 & 7.22 & 27692 & 6.22 \\
$\mathrm{P}_{2} \mathrm{O}_{5}(\mathrm{TSP})$ & 100 & 3.61 & & 3.60 \\
$\mathrm{~K}_{2} \mathrm{O}(\mathrm{KCl})$ & 75 & 2.71 & & 2.51 \\
\hline
\end{tabular}

Table 4. Biogas Waste Needs as a Substitute for Nutrient of Eggplant

\begin{tabular}{|c|c|c|c|c|c|c|c|c|c|c|}
\hline \multirow{2}{*}{ Nutrion Subtitution } & \multirow{2}{*}{$\begin{array}{c}\text { Required } \\
\text { waste } \\
(\mathrm{Kg})\end{array}$} & \multicolumn{3}{|c|}{ Biogas Waste Wombs } & \multicolumn{3}{|c|}{ Inorganic } & \multicolumn{3}{|c|}{ Required Fertilizer } \\
\hline & & $\mathbf{N}$ & $\mathrm{P}_{2} \mathrm{O}_{5}$ & $\mathrm{~K}_{2} \mathrm{O}$ & $\mathbf{N}$ & $\mathbf{P}_{2} \mathbf{O}_{5}$ & $\mathrm{~K}_{2} \mathrm{O}$ & Urea & SP-36 & KCL \\
\hline $0 \%$ & $0.00 *$ & 0.00 & 0.00 & 0.00 & 2.32 & 1.65 & 1.42 & 3.87 & 4.57 & 2.37 \\
\hline $20 \% \mathrm{~N}$ & $0.60 *$ & 0.46 & 0.33 & 0.15 & 1.86 & 1.32 & 1.27 & 3.10 & 3.67 & 2.12 \\
\hline $20 \% \mathrm{P}_{2} \mathrm{O}_{5}$ & 0.61 & 0.47 & 0.33 & 0.15 & 1.85 & 1.32 & 1.27 & 3.09 & 3.66 & 2.12 \\
\hline $20 \% \mathrm{~K}_{2} \mathrm{O}$ & 1.14 & 0.88 & 0.61 & 0.28 & 1.45 & 1.03 & 1.14 & 2.41 & 2.87 & 1.90 \\
\hline $40 \% \mathrm{~N}$ & $1.21^{*}$ & 0.93 & 0.65 & 0.30 & 1.39 & 1.00 & 1.12 & 2.32 & 2.77 & 1.87 \\
\hline $40 \% \mathrm{P}_{2} \mathrm{O}_{5}$ & 1.22 & 0.94 & 0.66 & 0.30 & 1.38 & 0.99 & 1.12 & 2.30 & 2.74 & 1.86 \\
\hline $40 \% \mathrm{~K}_{2} \mathrm{O}$ & $2.28 *$ & 1.75 & 1.23 & 0.57 & 0.57 & 0.42 & 0.85 & 0.95 & 1.16 & 1.42 \\
\hline
\end{tabular}

* Dose of biogas waste treated as treatment

Based on the results of the analysis there are differences in organic carbon content and cation exchange capacity (CEC) in the soil given biogas waste treatment. The land used for Eggplant planting media contains C-Organic as much as $1.49 \%$ which is included in the criteria of low COrganic content. The highest C-Organic content is in the treatment of giving $2.2 \mathrm{~kg}$ polybag ${ }^{-1}$ waste. The addition of sludge organic matter can increase C-Organic in the soil, which is $3.01 \%$ which is categorized as high (Table 5). The lowest organic $C$ value is found in the treatment of $0 \mathrm{~kg}$ of waste polybag ${ }^{-1}$ with a value of $1.53 \%$ organic $C$ which is categorized as low.

The treatment of giving organic fertilizer to the soil with low organic $C$ value can increase the C-organic content in the soil so that it can add nutrients. This addition of nutrients can influence on the growth and the yield of eggplant [8]. Based on the results of the research, increasing the dosage of organic fertilizer given increased the soil C-organic content.

Table 5. Characteristics of Soil after Waste Application

\begin{tabular}{llcll}
\hline Treatment & Analysis & Value & Unit & $\begin{array}{c}\text { Quality } \\
\text { Standard* }\end{array}$ \\
\hline $0 \mathrm{~kg}$ & C-Organik & 1.53 & $\%$ & Low \\
& KTK & 13.35 & $\mathrm{Cmol} \mathrm{kg}^{-1}$ & Low \\
\hline $0.6 \mathrm{~kg}$ & C-Organik & 2.39 & $\%$ & Moderate \\
& KTK & 16.40 & $\mathrm{Cmol} \mathrm{kg}^{-1}$ & Low \\
\hline \multirow{2}{*}{$1.2 \mathrm{~kg}$} & C-Organik & 2.95 & $\%$ & Moderate \\
& KTK & 20.99 & $\mathrm{Cmol} \mathrm{kg}^{-1}$ & Moderate \\
\hline \multirow{2}{*}{$2.2 \mathrm{~kg}$} & C-Organik & 3.02 & $\%$ & Moderate \\
& KTK & 13.75 & $\mathrm{Cmol} \mathrm{kg}^{-1}$ & Low \\
\hline
\end{tabular}

* Criteria for Assessing Soil Analysis Result of the 2009 Soil Research Center

Source: Research Center of Kopi and Kakao Jember and Laboratory of Soil Fertility, University of Jember (2018)

Based on the results of CEC measurements after treatment, it was found that the highest CEC was found in the treatment of $1.2 \mathrm{~kg}$ of waste polybag ${ }^{-1}$ with a value of $20.99 \mathrm{cmol} \mathrm{kg}^{-1}$ in 
the medium category and the lowest CEC in the treatment of $0 \mathrm{~kg}$ waste polybag ${ }^{-1}$ with a value of $13.35 \mathrm{cmol} \mathrm{kg}{ }^{-1}$ which was categorized low (table 5). But in general, the addition of sludge increases the soil CEC from before administration and after administration of sludge. This is because the sludge is included inorganic material so that it can increase CEC.

The increase in soil CEC due to the administration of organic matter is caused by decomposition of organic matter to produce organic compounds which can increase soil CEC [9]. The presence of organic matter in the soil chemical properties greatly affects the soil CEC in addition to the various nutrients contained in it which can also contribute to soil fertility [10].

CEC varies greatly on each type of land. The amount of soil CEC is influenced by the nature and characteristics of the soil itself, among others, soil reactions $(\mathrm{pH})$, soil texture or amount of clay, types of clay minerals, soil organic matter, calcification, and fertilization [11]. Based on the results of the study, although the content of C-organic soil increases the CEC value does not necessarily increase because the CEC value is also influenced by several other factors [12]. This is possible in the treatment of $2.2 \mathrm{~kg}$ of the waste polybag $^{-1}$ which is only KT $13.75 \mathrm{cmol} \mathrm{kg}^{-1}$.

\section{Effect of Biogas Waste on Growth and Yield of Eggplant}

The addition of biogas waste from cow manure on planting eggplant is done to increase the availability and uptake of nutrients. The results of the diversity of the observed variables are shown in Table 6 . Based on the results of variance analysis in table 6 , it shows that there is a treatment effect on plant height variables, flowering age, harvesting age, fruit diameter and fruit weight of cropping.

Table 6. Summary of $F$ count values and diversity coefficients on several observation variables

\begin{tabular}{lcc}
\hline $\begin{array}{c}\text { Observation } \\
\text { Variabel }\end{array}$ & $\begin{array}{c}\text { F-Count of dosage } \\
\text { Treatments for } \\
\text { Biogas }\end{array}$ & $\begin{array}{c}\text { Coefficient } \\
\text { of Varians }\end{array}$ \\
\hline Plant Height & $209.24^{* *}$ & 16.18 \\
Flowering Age & $21.42^{* *}$ & 19.92 \\
Harvesting Age & $69.16^{* *}$ & 7.14 \\
Fruit Diameter & $22.40^{* *}$ & 13.02 \\
Fruit Weight per & $64.27^{* *}$ & 4.60 \\
plant & &
\end{tabular}

Description: ${ }^{* *}$ ) Different is very real. ${ }^{*}$ ) Significantly different. ns): Different is not real

\section{Eggplant Plant Height (cm)}

Based on the results of the variance analysis in Table 7, the treatment of the sludge dose has a very significant effect on plant height on days 20 , $30,40,50$, and 60 and shows a different effect that is not significant on day 10 . This situation occurs because of the large possibility young plants do not have perfect roots, consequently, the roots cannot absorb nutrients optimally. Young plants will be able to absorb nutrients in small amounts, in line with the age of the plant, the speed of absorption of plant nutrients will increase if the age increases; according to its life cycle. Increasing the age of the plant, the need for nutrients increases and decomposes perfectly which can be fulfilled by the soil where it grows. Organic fertilizers given still need time to experience decomposition [13].

Table 7. Effects of Giving Biogas Waste on the Height of Eggplant

\begin{tabular}{lccccc}
\hline \multirow{2}{*}{ Treatment } & \multicolumn{5}{c}{ Day- } \\
\cline { 2 - 6 } & $\mathbf{2 0}$ & $\mathbf{3 0}$ & $\mathbf{4 0}$ & $\mathbf{5 0}$ & $\mathbf{6 0}$ \\
\hline $0 \mathrm{~kg}$ & $10.00^{\mathrm{ab}}$ & $24.88^{\mathrm{a}}$ & $50.55^{\mathrm{b}}$ & $76.53^{\mathrm{b}}$ & $86.58^{\mathrm{b}}$ \\
$0.6 \mathrm{~kg}$ & $10.03^{\mathrm{ab}}$ & $28.22^{\mathrm{b}}$ & $51.20^{\mathrm{b}}$ & $79.85^{\mathrm{c}}$ & $92.77^{\mathrm{c}}$ \\
$1.2 \mathrm{~kg}$ & $10.65^{\mathrm{b}}$ & $31.15^{\mathrm{c}}$ & $55.07^{\mathrm{c}}$ & $82.10^{\mathrm{d}}$ & $102.80^{\mathrm{d}}$ \\
$2.2 \mathrm{~kg}$ & $9.55^{\mathrm{a}}$ & $23.28^{\mathrm{a}}$ & $48.35^{\mathrm{a}}$ & $74.25^{\mathrm{a}}$ & $81.67^{\mathrm{a}}$ \\
\hline
\end{tabular}

Organic fertilizer has a slow nature of providing nutrients for plants because it requires time for the decomposition process (slowrelease). Fertilization using $100 \%$ inorganic has resulted in low efficient $\mathrm{N}$ absorption. This is due to $\mathrm{N}$ in Urea is fast release and immediately available for the plant, so that it is easily removed through washing, evaporation, and nitrification before it could be utilized by the plant. Deficient $\mathrm{N}$ during the generative phase will inhibit the formation and enlargement of the eggplant, and it will lead to low production [14].

The best treatment on plant height variables in the treatment of $1.2 \mathrm{~kg}$ polybag ${ }^{-1}$ waste dose with a final height of $102.8 \mathrm{~cm}$. While plant height is strongly influenced by the presence of $\mathrm{N}$ elements in the soil. In untreated soils, the administration of organic material in the form of sludge shows a lower height (Table 7) even though it has been fertilized using inorganic fertilizers. This can be caused by the not optimum absorption of fertilizers applied. The factor of $\mathrm{N}$ loss rate from urea fertilizer is between $60-80 \%$ in paddy fields and $40-60 \%$ on dry land; so that only $30-50 \%$ can be used by plants. This can be caused by the nutrient washing process by water (leaching) around the plant so that $\mathrm{N}$ becomes unavailable. Nutrient $\mathrm{N}$ is also easy to evaporate. $\mathrm{N}$ which losses through the evaporation process (volatility) may reach $70 \%$ [15]. 


\section{Flowering Age}

Figure 1 shows that the eggplant plant was given the treatment by adding organic material in the form of waste as much as $1.2 \mathrm{~kg} \mathrm{polybag}^{-1}$ has the average age of the fastest flowering and significantly different from the treatment without the provision of organic ingredients. The longest average age of flowering is found in the treatment of $2.2 \mathrm{~kg}$ of the waste polybag ${ }^{-1}$ with an average age of 35.83 HST. This can be caused by differences in the availability of $P$ elements in each treatment.

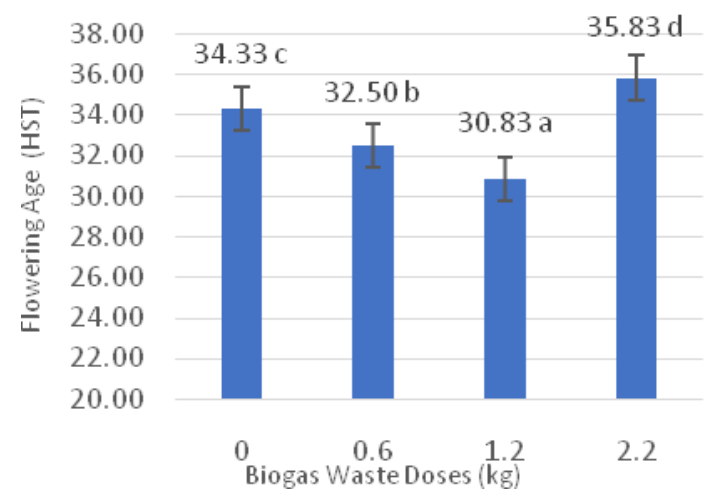

Figure 1. Effect of Giving Biogas Waste on Flowering Age of Eggplants

The availability of $P$ elements for plants serves to accelerate the flowering and cooking of fruits, seeds or grain and accelerate the percentage of flower formation into fruit or seed. Planting media that have been given organic material has increased levels of $P$ available, this is because phosphorus in the soil mostly comes from weathering of natural mineral rocks and the rest comes from weathering of organic matter. The form of phosphorus ions present in the soil also depends on the $\mathrm{pH}$ of the soil [16].

In the soil without the administration of organic ion $\mathrm{P}$ material, it will be bound by $\mathrm{Al}$ which is in the soil. The addition of organic material is one of the efforts that can be used to overcome the problem of civilization in the soil. Organic material in the decomposition process will release organic acids that can bind $\mathrm{Al}$ and form complex compounds so that Al becomes insoluble. Giving organic material is one way to accelerate the process of soil amelioration [17].

\section{Harvesting Age}

Figure 2 shows that eggplants are given the treatment of the addition of organic ingredients in the form of biogas waste $1.2 \mathrm{~kg}^{\text {polybag }}{ }^{-1}$ (L2) with the fastest average harvesting age (56.73 HST) and significantly different from the treatment without administration of organic material (LO) has an average harvest age of 60.17 HST. The longest average value of harvesting age was $2.2 \mathrm{~kg}$ of waste polybag-1 (L3) with an average of harvesting age of 61.03 HST. This can be caused by different elements in each treatment.

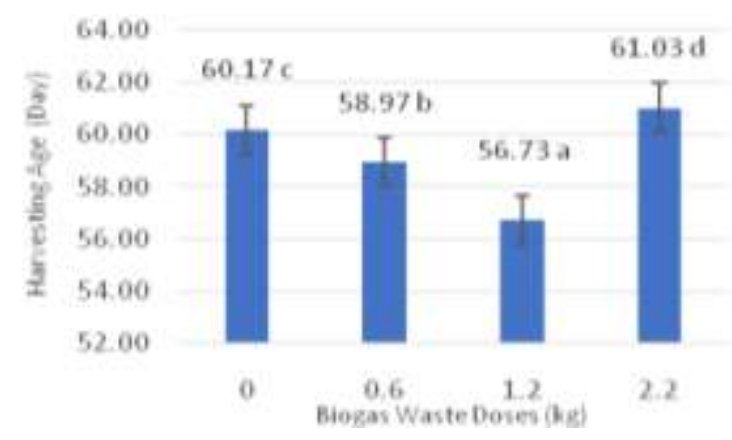

Figure 2. Effects of Giving Biogas Waste on Harvesting Age of Eggplants

The process of fertilizing and riping fruit requires sufficient $\mathrm{N}, \mathrm{P}$ and $\mathrm{K}$ nutrients. In the soil treated with $1.2 \mathrm{~kg}$ of waste polybag ${ }^{-1}$ (L2), the highest CEC value was 20.99. The availability of nutrients in the soil can be seen from the ability of the soil to exchange cations (CEC), the higher the CEC, the higher the ability to supply nutrients to plants. The fermentation process in the digester occurs anaerobic overhaul of organic matter into biogas and acid which has a low molecular weight which causes the concentration of $\mathrm{N}, \mathrm{P}$ and $\mathrm{K}$ to increase so that the CEC value of the soil that is given biogas waste is increased [18].

\section{Fruit Diameter}

Figure 3 showsed that the best treatment to produce the largest diameter is the treatment of biogas waste $1.2 \mathrm{~kg}^{\text {polybag }}{ }^{-1}$ (L2) dose, with an average fruit diameter of $35.94 \mathrm{~mm}$ and the lowest treatment $2.2 \mathrm{~kg}$ polybag ${ }^{-1}$ (L3) with a flat fruit diameter 32.57. This can be affected by the availability of nutrients. Fruit shaping is strongly influenced by the availability of nutrients for photosynthesis which produce carbohydrates, fats, proteins, minerals and vitamins which will be translocated into storage [19].

In the treatment of biogas waste, $1.2 \mathrm{~kg}$ polybag $^{-1}$ (L2) dose is able to provide a number of nutrients for generative development of plants, especially in the formation and ripening of fruit while in the treatment without giving waste (LO) and treatment of waste dose $2.2 \mathrm{~kg}^{\text {polybag }}{ }^{-1}$ (L3) fewer nutrients received. This can be seen in the CEC (Table 5) L2 land has a greater value than LO 
and L3. CEC values are related to the ability of the soil to provide nutrients to plants. The greater the value, the greater the ability of the soil to exchange its cations into plants.

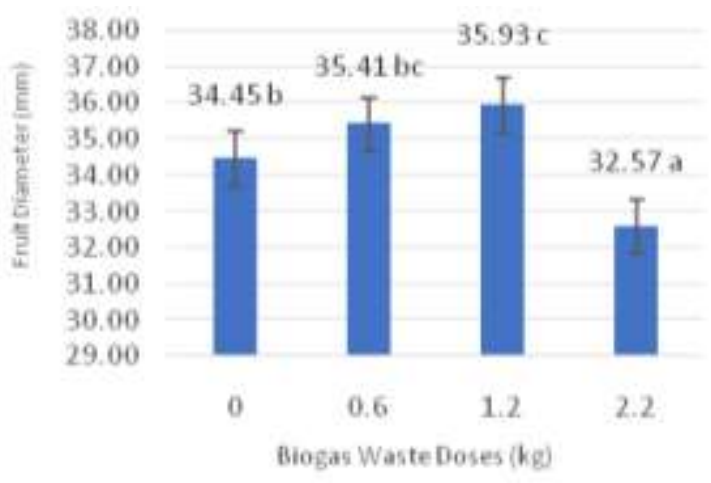

Figure 3. Effect of Giving Biogas Waste on Eggplant Diameter

Potassium has an important role in fruit shape. Potassium serves to increase the synthesis and translocation of carbohydrates for fruit filling [20]. Giving organic material that has an elemental content of potassium in the soil will increase the element of potassium, so potassium available for the soil will increase. The amount or amount of potassium absorbed by plants is strongly influenced by CEC (cation exchange capacity) and in general, soils with high CEC have the ability to store and provide greater $\mathrm{K}$ so vice versa, if the soil has a low CEC then the ability to store and provide $\mathrm{K}$ is also low [21].

\section{Fruit Weight per Plant}

Figure 4 shows that the best treatment to produce the best fruit weight per plant is the treatment of $1.2 \mathrm{~kg}$ polybag ${ }^{-1}$ biogas waste doses, having an average fruit weight of $1.36 \mathrm{~kg} \mathrm{plant}^{-1}$. Then, $2.2 \mathrm{~kg}$ polybag $^{-1}$ is the lowest dose of biogas waste with an average value of $0.99 \mathrm{~kg}$ plant $^{-1}$ weight. This situation is caused by the provision of biogas waste from cow manure can meet the nutrient needs of both macro and micro plants for eggplants and also due to improvements in physical trait and soil biological properties, so that eggplants can thrive and produce high fruit production. Exchangeable nutrients can be seen through CEC values (Table 5).

Biogas waste manure contains macro and micronutrients and microorganisms that are still active in the process of ferments and decomposition. The more organic matter given to plants will show a good response to support the growth and production of more optimal eggplant fruit. Availability of nutrients is very important for plant growth and development because nutrient content will help facilitate the metabolic processes of plants, including photosynthesis, so photosynthates are produced high, then translocated throughout parts of plants, especially the storage of food reserves such as fruit [22]. The availability of these nutrients at appropriate levels is advantageous for the full development of the plants as they are uptaken by plants from the soil after application[23].

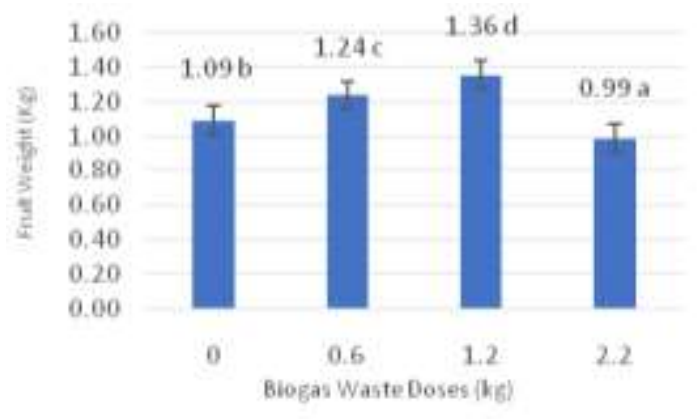

Figure 4. Effect of Biogas Waste on Fruit Weight Per Plant (Kg)

The application of biogas waste has not only provided nutrients, but also improving the physical, chemical, and biological features of the soil so that it could increase efficient absorption of the nutrients. Improvement on the soil features and the available nutrients have produced higher net assimilation rate for the eggplant [24]. Based on the research, the dosage of cow manure of biogas waste as an organic fertilizer affect the fruit weight of plants and crop production. the harvest yields of Leaf mustard were 2.3 and 2.2 times higher in the treatment supplied with inorganic fertilizers from codigester [25].

\section{CONCLUSION}

Based on the research that has been done, it can be concluded that the best treatment for achieving optimum plant height, fruiting age, harvesting age, fruit diameter, fruit length, and fruit weight is the treatment of using biogas waste with the dose of $1.2 \mathrm{~kg}$ polybag ${ }^{-1}$ (L2), with a height of $102.8 \mathrm{~cm}$, age of $30.83 \mathrm{HST}$, harvest age $56.73 \mathrm{HST}$, fruit diameter $35.93 \mathrm{~mm}$, fruit length $17.95 \mathrm{~cm}$ and fruit weight of crop reached $1.36 \mathrm{~kg}$ (37.61 tons $\left.\mathrm{ha}^{-1}\right)$.

\section{REFERENCES}

[1] Kasyap, S., S. Kumar, S. Maji, D. Kumar. 2014. Effect of organic manures and inorganic fertilizers on growth, yield and quality of brinjal (Solanum melongena L.) cv. 
Pant Rituraj. Inter. J. Agric. Sci. 10(1). 305308.

[2] Anwar, A., Rahmi, D.H.R, M. Bahar. 2017. Pengaruh kombinasi pupuk NPK dan urine kambing terhadap tanaman terong (Solanum melongena L.) pada fase pertumbuhan dan hasil tanaman di polybag. Wahana Inovasi. 6(2). 157-169.

[3] Anastasia, P., D.A. Hanang. 2014. Statistik produksi hortikultura tahun 2014. Ministry of Agriculture. Directorate General of Horticulture. Jakarta.

[4] Waseem, K., A. Hussain, M.S. Jilani, M. Kiran, Ghazanfarullah, S. Javeria, A. Hamid. 2013. Nutritional management in brinjal (Solanum melongena L.) using different growing media. Pak. J. Sci. 65(1). 21-25.

[5] Sari, W.U., H.S. Bambang, E. Hanudin. 2014. Pengaruh limbah biogas sapi terhadap ketersidiaan hara makro-mikro inceptisol. Tanah dan Air. 11(1). 12-21.

[6] Maruapey, A. 2015. Pengaruh pupuk organik limbah biogas cair kotoran sapi terhadap pertumbuhan dan produksi tanaman jagung manis (Zea mays saccharata Sturt.). Agroforestri. 10(3). 191-200.

[7] Shahid, U., A. Imran, S. Kamran, M. Asad, Z. Bibbi, N. Jan. 2017. Effect of organic mature and inorganic fertilizer on the quality of eggplant cultivars. Biology. 7(17). 107-114.

[8] Nuryadin, I., D.R. Nugraha, Y. Sumekar. 2016. Pertumbuhan dan hasil kubis bunga (Brassica oleracea var botrylis L.) kultivar bareta 50 terhadap kombinasi pupuk anorganik dan pupuk organik. IImu Pertanian dan Peternakan. 4(2). 259-268.

[9] Sembiring, I.S., Wawan, M. Amrul K. 2015. Sifat kimia tanah dystrudepts dan pertumbuhan akar tanaman kelapa sawit (Elaeis guineensis Jacq.) yang diaplikasikan mulsa organik Mucuna bracteata. Jom Faperta. 2(2). 1-11.

[10] Lumbanraja, P., M.H. Erwin. 2015. Perbaikan kapasitas pegang air dan kapasitas tukar kation tanah berpasir dengan aplikasi pupuk kandang pada ultisol Simalingkar. Pertanian Tropik. 2(1). 53-67.

[11] Hanafiah, A.K, 2005. Dasar-dasar ilmu tanah. PT Raja Grafindo Persada. Jakarta.

[12] Arviandi, R., A. Rauf, G. Sitanggang. 2015. Evaluasi sifat kimia tanah inceptisol pada kebun inti tamanan gambir (Uncaria gambir Roxb.) di Kecamatan Salak Kabupaten Pakpak Bharat. Agroteknologi. 3(4). 13291334.
[13] Maghfoer, M.D., R. Soelistyono, N. Herlina. 2014. Growth and yield of eggplant (Solanum melongena $\mathrm{L}$ ) on various combination of $\mathrm{N}$-Source and number of main branch. Agrivita. 36(3). 285-294.

[14] Gardner, F.P., R.B. Pearce, R.L. Mitchell. 1991. Physiology of crops plants. Scientific Publisher. Jodhpur, India.

[15] Malav, L.C., A.K. Shakeel, N. Gupta. 2015. Effects of biogas slurry incorpotation on yield and growth attributes of baby corn (Zea mays L). Green Farming. 6(6). 156-159.

[16] Novizan. 2002. Petunjuk pemupukan yang efektif. Agromedia Pustaka. Jakarta.

[17] Siregar, P., Fauzi, Supriadi. 2017. Pengaruh pemberian beberapa sumber bahan organik dan masa inkubasi terhadap beberapa aspek kimia kesuburan tanah utisol. Agroteknologi. 5(2). 256-264.

[18] Simamora, S., Salundik, S. Wahyuni. 2006. Membuat biogas pengganti bahan bakar minyak dan gas dari kotoran ternak, $1^{\text {st }} \mathrm{Ed}$. Agromedia Pustaka. Jakarta.

[19] Jumin, H.B. 1992. Ekologi tanaman. Rajawali Press. Jakarta.

[20] Nuraini, A., D. Sobardini., E. Suminar, H. Apriyanto. 2016. Kuantitas dan kualitas hasil benih buncis tegak (Phaseolus vulgaris L) yang diberi pupuk organik padat dan pupuk organik cair chitosan. Kultivasi. 15(2). 81-85.

[21] Wanarso, S. 2005. Kesuburan tanah. Gava Media. Yogyakarta

[22] Refliaty, G. Tampubolon, Hendriansyah. 2012. Pengaruh pemberian kompos sisa biogas kotoran sapi terhadap perbaikan beberapa sifat fisik ultisol dan hasil kedelai (Glycine max (L.) Merill). Hidrolitan. 2(3). 103-114.

[23] Kumar, S., C.M. Lal, K.M. Mahesh, S.A. Khan. 2015. Biogas slurry : source of nutrients for eco-friendly agriculture. Ext. Res. 2(1). 1-5.

[24] Nyang'au, J., A. Stephen, E. Gatebe. 2016. Evaluation of biogas slurry as an alternative organic fertilizer: a case study in Kenya. Ext. Res. 9(10). 1-5.

[25] Gulshan, A.B., H.M. Saeed, S. Javidi, T. Meryem, M.I. Atta, M. Aminuddin. 2013. Effects of animal manure on the growth and develop-ment of okra (Abelmoschus esculentus L.). J. Agr. Biol. Sci. 8(3). 213-219.

[26] Nguyen, V.C.N., M.H. Hong, N.L. Phan, T.N.L. Nguyen, C.M. Pham, T.N. Kieu, and M.T. Pham. 2015. Co-Benefits from applying codigester's sludge to farming activities in Mekong Delta. Health Environ. 1(1). 30-44. 